\title{
An assessment of the magnitudes and factors associated with postharvest losses in off-farm grain stores in Kenya
}

\author{
Joseph K. Mwangi a, b, Christopher M. Mutungi a, b, *, Soul-Kifouly G. Midingoyi a , \\ Abdul K. Faraj ${ }^{\text {b }}$, Hippolyte D. Affognon ${ }^{c}$ \\ a International Centre of Insect Physiology and Ecology (icipe), Nairobi, Kenya \\ ${ }^{\mathrm{b}}$ Department of Dairy and Food Science and Technology, Egerton University, P.O. Box 536-20115, Egerton, Kenya \\ ${ }^{\mathrm{c}}$ International Crops Research Institute for the Semi-Arid Tropics (ICRISAT), BP 320, Bamako, Mali
}

\section{A R T I C L E I N F O}

\section{Article history:}

Received 14 February 2017

Received in revised form

29 May 2017

Accepted 29 May 2017

\section{Keywords:}

Postharvest

Off-farm storage

Maize

Losses

Kenya

\begin{abstract}
A B $S T R$ A C $T$
Off-farm grain storage is an important postharvest undertaking by government, traders and processors in Kenya. A survey was conducted in 2014/2015 to assess the kinds and magnitudes of perceived losses experienced in off-farm stores, and the factors associated with them. Store supervisors or key personnel charged with grain storage in 39 public and 74 private stores, spread across the six maize growing agroecological zones, were interviewed using a structured questionnaire. Total perceived losses averaged $17.6 \pm 2.3 \%$, and were attributed to insects $(7.2 \pm 1.0 \%)$, molds $(5.7 \pm 2.1 \%)$, moisture loss $(3.4 \pm 0.5 \%)$, rodents $(2.0 \pm 0.5 \%)$, spillage $(0.50 \pm 0.0 \%)$ and birds $(0.10 \pm 0.0 \%)$. Total losses experienced in public and privately owned stores were not significantly different. The losses attributed to insect and the vertebrate pests, moisture loss and spillage, were also not significantly different in the two storage systems. However, losses due to molds were significantly higher in the private stores. From regression analysis, higher losses were associated with the use of residual insecticides, purchasing low quality maize for storage, reuse of storage bags, untimely control of storage pests, and the agro-climatic conditions of the moist transitional, moist mid-altitude and dry mid-altitude zones. Relying on infestation reports to initiate pest control had the highest marginal effect (21.7\%). Lower loss magnitudes were associated with cleaning and drying grain before storage, early pest control and storage periods shorter than two months. These findings provide important reasons for appraising current off-farm storage techniques with a view to taking possible actions for improvements. It is recommended that innovations to mitigate maize postharvest losses should also target off-farm storage, as the losses incurred are significant.
\end{abstract}

(c) 2017 Elsevier Ltd. All rights reserved.

\section{Introduction}

Food grains support the nutrition of many households in Kenya (Jayne and Argwings-Kodhek, 1997). Consequently, individual farmers, traders, and the government undertake storage for food security or commercial reasons. Maize is the most important food grain followed by common beans (Mauyo et al., 2007). Other food grains include rice, wheat, sorghum, millet, green grams, cowpeas and pigeon peas. Local production of these commodities is, however, not sufficient to meet the local food demand. For this reason, imports are received from other countries to fill the demand gap

\footnotetext{
* Corresponding author. International Centre of Insect Physiology and Ecology (icipe), Nairobi. Kenya.

E-mail address: cmutungi@icipe.org (C.M. Mutungi).
}

(FAOSTAT, 2016). The government also maintains strategic grain reserves in public warehouses through the National Cereals and Produce Board (NCPB) to provide a buffer against extreme shortage, distribute as relief food in case of emergency, or intervene in markets when the need arises (Lewis et al., 2005).

Since liberalization of the Kenyan grain marketing system in the 1990s, private actors play a greater role in grain handling (Jayne and Argwings-Kodhek, 1997). The NCPB and large millers control $15-20 \%$ of locally produced maize (FAO, 2013), thus about $80 \%$ of harvested maize is handled or stored in less centralised systems by farmers and other small-scale grain handlers who include aggregators, wholesalers, retailers, and small millers. Storage is important because it evens out seasonal supply fluctuations (Adejumo and Raji, 2007). Inadequate storage facilities, however, encourage deterioration leading to quantity or quality losses (World Bank, 2010). During off-farm storage, losses may occur through spillage, 
defective bagging, slow delivery to store or market, and contamination or damage by pests. For traders, such losses lower their revenues because saleable weight is diminished, and low quality grain is sold, disposed at discounted prices (Compton et al., 1998) or discarded (Golob and Hodges, 1982). According to the African Postharvest Losses Information System (APHILIS, 2016) quantity losses of cereals in sub-Saharan Africa (SSA) accumulate to 10-23\% from harvesting to market storage. This source attributes $2-4 \%$ of the losses to market storage. A recent meta-analysis (Affognon et al., 2015), however, revealed that data on grain losses at levels other than on-farm storage are rather limited, casting the need to generate more data so as to inform policy and postharvest losses mitigation decisions.

Traditionally in East Africa, the grain weevil (Sitophilus spp. Coleoptera: Curculionidae) and the Angoumois grain moth (Sitotroga cerealella (Olivier) Lepidoptera: Gelechiidae) on cereals, and three genera of the family Chrysomelidae, sub-family Bruchinae (Acanthoscelides, Zabrotes and Callosobruchus), are notorious insect pests in grain stores (Abate et al., 2000). In the early 1980s, the larger grain borer (Prostephanus truncatus, (Horn) Coleoptera: Bostrichidae) emerged as an even more harmful pest for stored maize in East Africa (Golob and Hodges, 1982). In addition to these pests, moisture loss, infection by molds and infestation by rodents and birds also cause significant losses especially on cereals (Lathiya et al., 2007; Edoh-Ognakossan et al., 2016). Molds may cause mycotoxin contamination (Wagacha and Muthomi, 2008), whereas rodents and birds may cause physical losses, and contaminate the grain with substances that degrade the quality (Cao et al., 2002; Gwinner et al., 1996).

Effective control of pests and contaminations during storage is a challenge in SSA. Infestations begin on the farm, continue in farmers' stores, and end up in off-farm storage facilities. One challenge of off-farm grain storage in SSA is the lack of purposebuilt storage facilities (World Bank, 2010). First, small and medium grain handlers frequently store in unsuitable spaces, usually created by converting existing idle premises. Such stores may not meet the requirements for good grain storage (Wilkin and Row lands, 1988). Secondly, in the majority of commercial stores, insect infestation is destroyed by fumigation, occasionally combined with spray treatment of bag stacks and store surfaces with synthetic insecticides as hygiene measure (World Bank, 2010). If proper treatment regimes are not consistently followed, insects may evolve resistance against the fumigants (Benhalima et al., 2004; Taylor, 1991; Chaudhry, 1997) or residual insecticides (Odeyemi et al., 2010) further complicating the problem. Furthermore, the storage of large volumes of grain increases the difficulties of detecting and dealing with infestations in many stores (Wilkin and Row lands, 1988). To the best of our knowledge, no systematic studies have assessed losses in off-farm grain stores in Kenya; most past assessments targeted on-farm storage. The aim of the present study was therefore to assess the kinds and levels of postharvest losses in government and privately owned stores as perceived by the persons directly responsible for grain storage. A further objective was to identify the factors associated with the losses. Making such information available is important because it will enable the postharvest sector to contribute more reliable data to forecasts of food availability, while enabling relevant actors to take practical decisions to mitigate the losses.

\section{Materials and methods}

\subsection{Study area}

The study was carried out in six maize Agro ecological zones (AEZs) of Kenya (Fig. 1). The AEZs are classified according to maize production potential (Hassan et al., 1998), and include: the highland tropical (HLT), moist transitional (MT), moist mid-altitude (MMA), dry mid-altitude (DMA), dry transitional (DT), and the lowland tropical (LLT). Characteristics of the six zones are described in Table 1. The HLT and MT are high potential zones; together they represent $64 \%$ of the total production area and account for approximately $80 \%$ of Kenya's maize production. The DMA and MMA zones have medium potential, whereas LLT and DT zones are low potential areas (De Groote, 2002). The HLT zone experiences a uni-modal rainfall pattern whereas the rest have bimodal rainfall patterns. Storage begins in March/April and August/September in regions that have bi-modal rainfall pattern and in October/ November in regions with mono-modal rainfall.

\subsection{Sampling and data collection}

A survey was conducted between October 2014 and March 2015. First, a literature search was conducted to establish a comprehensive list of documented grain warehouses and stores in Kenya. Key data sources included the National Cereals and Produce Board (NCPB; http://www.ncpb.co.ke/), the Eastern Africa Grain council (EAGC; http://eagc.org/), Regional Agricultural Trade Intelligence Network (RATIN; http://www.ratin.net/), and previous grain value chain reports (e.g. USAID). From these sources, a list of 336 stores comprising 110 public warehouses (PWs) and 226 private stores (PSs) was compiled. Using the formula described by Yamane (1967), with a precision level of $10 \%$ where confidence level is $95 \%$ and $p=0.5$, a sample of 121 stores was determined to be sufficient. The sample was purposively drawn so as to obtain representation of all agro-ecological zones. Out of this sample, 31 (25.6\%; $N=121)$ of the stores declined to participate in the survey and these were replaced using the snow ball sampling technique, in which the respondent in a store included in the sample referred the research team to other stores in the locality from which a suitable replacement was made. A final sample of 113 stores comprising 39 PWs and 74 PSs was surveyed. Face to face interviews were conducted using a structured questionnaire. Data on socio-economic characteristics of respondents, warehouse/store characteristics, grain sources and target markets, storage practices, storage problems experienced, strategies for coping with the storage problems, and the proportion of grain lost during the immediate previous storage season as recalled by each respondent were recorded. To assist in estimation of losses, respondents were each taken through a brief training session on storage losses. Pictorial images of different storage pests and loss scenarios were presented to help them recognize various forms of losses they may have experienced. Respondents were then asked to estimate the number of bags lost due to different causes relative to the number of $90 \mathrm{~kg}$ bags initially stored.

\subsection{Data analysis}

Data on socio-demographic characteristics of respondents, warehouse characteristics, storage practices, storage problems, and the various approaches used to address storage problems were expressed as percentages, and summarized in contingency tables or graphs. Differences within categories in each warehouse type, as well as the overall sample were determined using the Chi-square test followed by pairwise comparisons using "chisq.multcomp" function with Bonferroni $p$-values adjustment in the RVAideMemoire package in $\mathrm{R}$ 3.2.5 software. Losses data, which were reported by respondents as percentage of the total amount of grain stored, were presented as means. Prior to analysis data on loss magnitudes (\%) were arcsine square root (x/100)-transformed and tested for normality using the Shapiro-Wilk test. The data were not normally distributed even after transformation: $d f=113$, 


\section{Legend}

- Sampled warehouses

Maize agro-ecological zones
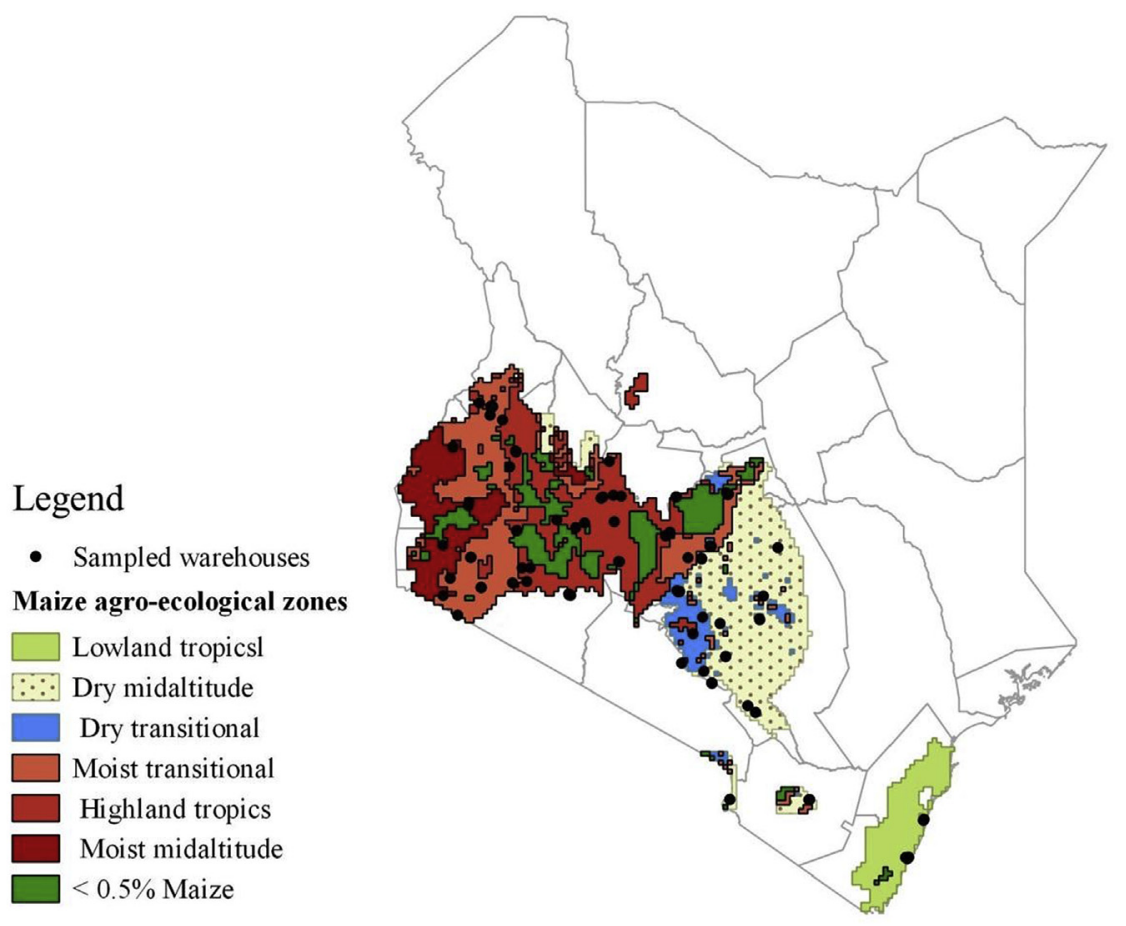

0

60000

$120000 \mathrm{~km}$

Fig. 1. Map of Kenya showing the various agro-ecological zones and localities surveyed during the study.

Table 1

Characteristics of maize growing agro-ecological zones of Kenya.

\begin{tabular}{|c|c|c|c|c|}
\hline \multirow[t]{2}{*}{ Agro-ecological zones } & \multirow[t]{2}{*}{ Altitude (m a.s.l ${ }^{\mathrm{g}}$ ) } & \multirow[t]{2}{*}{ Average total seasonal rainfall $(\mathrm{mm})$} & \multicolumn{2}{|c|}{ Daily temperature $\left({ }^{\circ} \mathrm{C}\right)$} \\
\hline & & & Min. & Max. \\
\hline LLT $^{a}$ & $<800$ & $<1000$ & 20.0 & 29.4 \\
\hline DMA $^{\mathrm{b}}$ & $700-1300$ & $<600$ & 16.1 & 27.9 \\
\hline $\mathrm{DT}^{\mathrm{c}}$ & $1100-1800$ & $<600$ & 14.0 & 25.3 \\
\hline HLT $^{d}$ & $>1600$ & $>400$ & 10.0 & 23.0 \\
\hline $\mathrm{MT}^{\mathrm{e}}$ & $1200-2000$ & $>500$ & 13.4 & 23.3 \\
\hline MMA $^{f}$ & $1100-1500$ & $>500$ & 15.9 & 28.3 \\
\hline
\end{tabular}

a Lowland tropical zone.

b Dry mid-altitude zone.

c Dry transitional zone.

d Highland tropical zone.

e Moist transitional zone.

${ }^{f}$ Moist mid-altitude zone.

g Above sea level. Source: Hassan et al. (1998).

statistic $=0.658, P<0.001$ (insect losses); $d f=113$, statistic $=0.484$, $P<0.001$ (rodent losses); $d f=113$, statistic $=0.699,<=0.001$ (spillage losses); $d f=113$, statistic $=0.484, P<0.001$ (moisture losses); ( $\mathrm{df}=113$, statistic $=0.746, P<0.001$ (losses due to molds); $d f=113$, statistic $=0.602, P<0.001$ (losses due to birds) and $d f=113$, statistic $=0.639, P<0.001$ (total losses). For this reason, Wilcoxon Mann-Whitney test and Kruskal-Wallis test, which does not require the assumption of normal distribution to be met, were used to test for statistical differences on Stata SE version 12 (StataCorp LP, Texas, USA) and 'agricolae' package in R 3.2.5 software respectively.

To establish the factors associated with losses, multivariate regression analysis was performed. Some stores/warehouses reported no losses, and for these, the losses were constrained to zero. Moreover, the dependent variable (the proportion of maize lost) was censored at both right and left sides to be within the $(0-1)$ range. The censored regression model (i.e. the Tobit model) is often used to address data observed on the closed interval $[0,1]$ (e.g. Agnew et al., 1995). As Maddala (1991) observes, a Tobit model is appropriate to describe censored data in the interval $[0,1]$ but its application is very stringent in terms of assumptions, requiring normality and homoscedasticity of residuals. The approach that handles such fractional data observed on the closed interval $[0,1]$ (e.g. Bastos (2010), Carpenter et al. (2009), Grippa et al. (2005)) is the fractional logit model (FLM) proposed by Papke and Wooldridge (1996). The estimation procedure of the fractional response model of Papke and Wooldridge is a quasi-likelihood method (QLM) that consists of the maximization of the Bernoulli log-likelihood function. The following multiple linear regression function was specified in the present study: 


$$
\begin{aligned}
Y= & a_{0}+a_{1} x_{1}+a_{2} x_{2}+a_{3} x_{3}+a_{4} x_{4} \\
& +a_{5} x_{5} \ldots \ldots \ldots \ldots \ldots \ldots \ldots a_{25} x_{25}+e
\end{aligned}
$$

where the dependent variable $Y$ is magnitude of perceived losses, and the explanatory variables $x_{1}$ to $x_{25}$ are storage condition factors and storage practices as follows:

$x_{1}$ : highland tropical zone; $x_{2}$ : moist transitional zone; $x_{3}$ : moist mid-altitude zone; $x_{4}$ : dry mid-altitude zone; $x_{5}$ : dry transitional zone; $x_{6}$ : store ownership type (dummy $=$ ' 1 ' if public, ' 0 ' if private); $x_{7}$ : training on grain postharvest management (dummy $={ }^{\prime}{ }^{\prime}$ if trained, ' 0 ' if not trained); $x_{8}$ : source maize from imports; $x_{9}$ : source maize from inter-depot transfer; $x_{10}$ : aggregate grains; $x_{11}$ : use jute bags; $x_{12}$ : use woven polypropylene bags; $x_{13}$ : use standards; $x_{14}$ : buy low quality grain; $x_{15}$ : stores for $<2$ months; $x_{16}$ : stores for $>12$ months; $x_{17}$ : dry grains before storage; $x_{18}$ : clean grains before storage; $x_{19}$ : use residual pesticides; $x_{20}$ : rely on infestation reports for treatment; $x_{21}$ : apply pesticides within first month; $x_{22}$ : apply pesticides after close of purchases; $x_{23}$ : proper sewing of bags; $x_{24}$ : sell to local retailers; $x_{25}$ : sell to miller; $e=$ random error.

\section{Results}

\subsection{Socio-demographic characteristics of respondents}

Table 2 summarizes the socio-demographic characteristics of respondents according to the type of warehouse. Three quarters of the respondents in the PWs were men, while men and women were equally represented in the PSs. More than $90 \%$ of the respondents were aged between 25 and 55 years, but more youthful persons (age $<34$ years) owned or managed the PSs compared to PWs. More than $80 \%$ of all respondents had attained secondary education. The proportion of respondents with secondary education was, however, higher in PWs than in PSs; close to $10 \%$ of the respondents in PSs had not completed primary education, or did not have formal education at all. Less than half of respondents had received training, and the proportion of respondents who did not have training was significantly higher in the PSs $\left(\chi^{2}(1)=33.38, P<0.001\right)$ compared to PWs.

\subsection{Characteristics of stores}

All the PWs were government-owned. The PSs were owned by small and medium enterprises (SMEs) or private companies (91.9\%), co-operative societies (8.1\%), farmers groups $(4.1 \%)$ and non-government organization (1.4\%). About three quarters of the PSs (73\%) were managed by operators who rented premises from a primary owner, while about one quarter (25.7\%) were managed by owners operating from self-owned premises. Fig. 2 summarizes the functions (Fig. 2a) and construction characteristics (Fig. 2b) of the stores. The PWs stocked grain mainly for food relief and strategic reserve but were also involved in retail selling. The PSs majored in short-term storage functions including grain aggregation or holding while waiting for favorable retail prices. Slightly more than a third of the PSs held the grain awaiting further processing (Fig. 2a). All PWs were purpose-built for grain storage whereas more than two thirds of the PSs were ordinary premises that converted to storage spaces (Fig. 2b). Generally, the stores were constructed of concrete, corrugated iron sheet or timber walls, with iron sheet or concrete roofing.

\subsection{Grain storage practices}

The types and sources of grains stored, and the pre-storage practices are presented in Table 3. All the PWs stored maize and some also stored rice, beans, wheat, sorghum, barley or millet. Similarly, all PSs stored maize, while some stored beans, millet, sorghum, wheat and rice. The proportion of stores stocking beans, wheat, millet and sorghum was significantly higher in PSs than PWs $(\chi 2(1)=9.753, P=0.002$ (beans); $\chi 2(1)=13.275, P<0.001$ (wheat); $(\chi 2(1)=29.289, P<0.001$ (millet); and $\chi 2(1)=25.004$, $P<0.001$ (sorghum), while the proportion of stores that stocked rice was significantly higher in PWs. $(\chi 2(1)=14.664, P<0.001)$. Overall, beans and rice were stored in slightly more than half of the stores. Millet, sorghum and wheat were stored in about a third of the stores.

All PWs received grain from individual farmers and retail brokers (intermediaries), while some was also received from interdepot transfers, cooperative societies, imports, and contracted farmers. The PSs received grains from the same sources, except inter-depot transfers and the receipts from co-operative societies were significantly less frequent $(\chi 2(1)=4.473, P=0.034)$. Redrying, cleaning and weight standardization of received grain were common pre-storage practices. However, considering PWs and PSs together, only less than $50 \%$ of stores performed weight standardization, re-dried, or cleaned the grain before storage.

Table 2

\begin{tabular}{|c|c|c|c|}
\hline \multirow[t]{2}{*}{ Parameter } & \multicolumn{3}{|c|}{ Proportion of stores (\%) } \\
\hline & $\operatorname{PWs}^{\mathrm{a}}(N=39)$ & $\operatorname{PSs}^{\mathrm{b}}(N=74)$ & Overall $(N=113)$ \\
\hline \multicolumn{4}{|l|}{ Age (years) } \\
\hline Below 18 & 0.0 & 0.0 & 0.0 \\
\hline $18-24$ & 0.0 & 6.8 & 4.4 \\
\hline $25-34$ & 18.0 & 35.1 & 23.9 \\
\hline $35-44$ & 33.3 & 28.4 & 30.1 \\
\hline $45-54$ & 43.6 & 18.9 & 27.4 \\
\hline 55 and above & 5.1 & 10.8 & 8.9 \\
\hline \multicolumn{4}{|l|}{ Gender } \\
\hline Men & 76.9 & 51.4 & 60.2 \\
\hline Women & 23.1 & 48.7 & 39.8 \\
\hline \multicolumn{4}{|l|}{ Level of Education } \\
\hline Completed secondary school & 92.3 & 78.4 & 83.2 \\
\hline Completed primary school & 7.7 & 12.2 & 10.6 \\
\hline Not completed primary school & 0.0 & 4.1 & 2.7 \\
\hline No formal education & 0.0 & 5.4 & 3.5 \\
\hline Trained on grain storage and protection & 76.9 & 24.4 & 42.5 \\
\hline
\end{tabular}

Socio-demographic characteristics of respondents.

a Public warehouses.

b Private stores. 
a

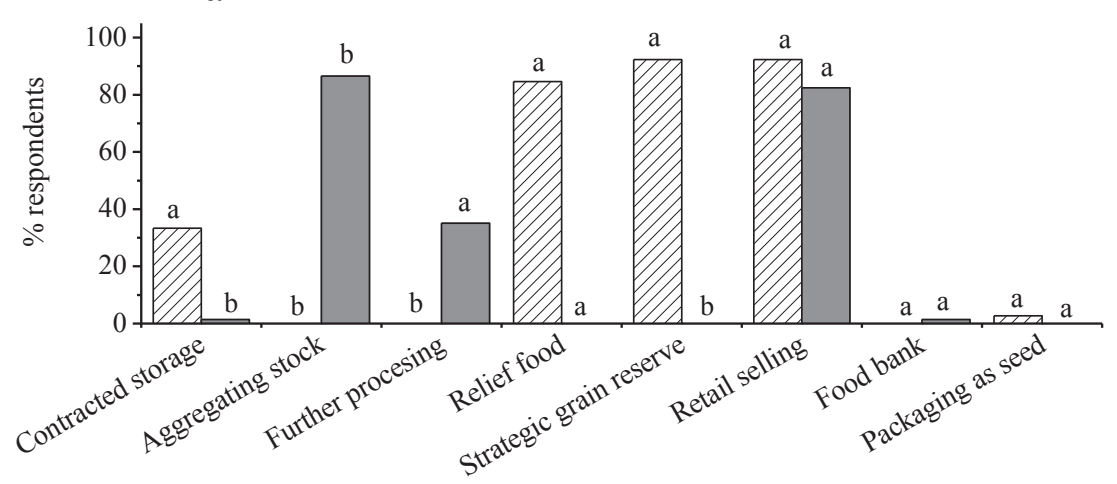

b

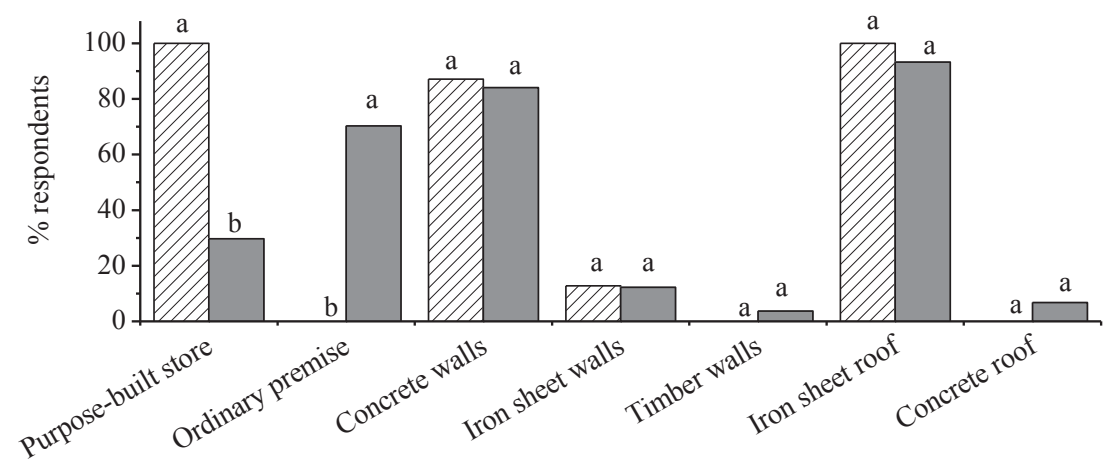

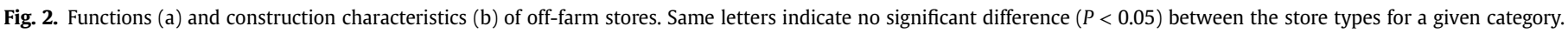

Moreover, some stores purchased low quality grain if sold at a lower price. Compared to PWs, a significantly higher proportion of the PSs re-dried the grain before storage $(47.3 \% ; \chi 2(1)=9.420$, $P<0.001)$, and accepted low-quality grains (37.8\%; $\chi 2(1)=19.618$, $P<0.001)$, while a significantly lower proportion performed weight standardization (36.5\%; $\chi 2(1)=9.341, P=0.002$ ).

Table 4 shows the quality parameters that were frequently analyzed during grain purchase, and the extent to which stores complied with local standards while making purchase decisions. The specific standards refer to those stipulated by the Kenya Bureau of Standards (KEBS). Generally, all PWs examined all parameters and applied purchasing criteria that matched with KEBS standards. However, not all PSs examined the grain for the various parameters. Compared to PWs, a significantly lower proportion of PSs examined foreign matter $(\chi 2(1)=12.0375, P=0.001)$ inorganic matter $(\chi 2$ $(1)=72.765, P<0.001)$, broken grains $(\chi 2(1)=37.976, P<0.001)$, pest damage $(\chi 2(1)=5.153, P=0.023)$, rotten and diseased grains $(\chi 2(1)=5.934, P=0.015)$, discolored grains $(\chi 2(1)=17.79$, $P<0.001)$, shriveled grains $(\chi 2(1)=35.229, P<0.001)$ and aflatoxin contamination $(\chi 2(1)=68.456, P<0.001)$. Moisture content and live insect infestation were the most frequently analyzed parameters by PS, whereas inorganic matter and aflatoxin were the least frequently analyzed. The levels of compliance to standards were also significantly lower for most parameters as compared to PWs.

Methods and duration of grain storage are summarized in Table 5. Targeted buyers of the grain are presented in Fig. 3, as well as the approaches used to manage any deteriorated grain lots (Fig. 3b). Grains were stored in bags or in bulk. In the overall sample, woven polypropylene (WPP) bags were more popular than jute bags. All PWs used jute bags, but a significant two thirds also used WPP bags. A majority of PSs used WPP bags; storage in jute bags and silos was significantly less frequent in PSs compared to PWs (Jute bags: $\chi 2(1)=86.742, P<0.001$; Silo: $\chi 2(1)=13.724$, $P<0.001)$. A significantly higher proportion of PWs (92.3\%) stored grains for longer than 12 months $(\chi 2(1)=50.767, P<0.001)$ while a significantly higher proportion of PSs stored for less than two months $(\chi 2(1)=100.244, P<0.001)$. As shown in Fig. $3 a$, the targeted buyers of stored grain were similar for PWs and PSs, except that a significantly larger proportion of the PSs sold to retailers $(\chi 2$ $(1)=8.507, P=0.004$ ) while a significantly higher proportion of PWs sold to food relief agencies $(\chi 2(1)=43.486, P<0.001)$. All stores reported grain deterioration in the course of storage. Whereas a significantly higher proportion of about three quarters of the PWs destroyed any deteriorated grain $(\chi 2(1)=46.835$, $P<0.001$ ), only $10.8 \%$ of the PSs did so (Fig. $3 \mathrm{~b}$ ). The PSs, more frequently, responded by selling immediately, applying insecticides, blending with good quality grain or selling for animal feed. With the exception of treatment with insecticides, the frequencies of these practices were significantly higher in PSs (immediate selling: $\chi 2(1)=30.642, P<0.001$; sell for animal feed: $\chi 2$ $(1)=6.121, P=0.013$; blending with good quality grains: $\chi 2$ $(1)=25.631, P<0.001$; re-drying and treating with insecticides: $\chi 2$ $(1)=7.742, P=0.005)$.

\subsection{Storage problems}

The kinds and nature of problems encountered during storage are presented in Fig. 4. Nearly three quarters of PWs ranked insect damage as a 'very important' storage problem, whereas more than 
Table 3

Types and sources of grains, and common practices applied before storage.

\begin{tabular}{|c|c|c|c|}
\hline \multirow[t]{2}{*}{ Parameter } & \multicolumn{3}{|c|}{ Proportion of stores (\%) } \\
\hline & $\mathrm{PW}^{\mathrm{a}}(N=39)$ & $\operatorname{PS}^{\mathrm{b}}(N=74)$ & Overall $(N=113)$ \\
\hline \multicolumn{4}{|l|}{ Grains stored } \\
\hline Maize & 100a, A & 100a, A & $100 \mathrm{a}$ \\
\hline Beans & $38.46 b, \mathrm{~B}$ & 68.92ab, A & $58.41 b$ \\
\hline Wheat & $12.82 \mathrm{bc}, \mathrm{B}$ & $47.3 \mathrm{~b}, \mathrm{~A}$ & $35.4 b$ \\
\hline Millet & $2.56 \mathrm{c}, \mathrm{B}$ & 54.05ab, A & $36.28 b$ \\
\hline Sorghum & $5.18 c, \mathrm{~B}$ & $52.7 \mathrm{~b}, \mathrm{~A}$ & $36.28 b$ \\
\hline Rice & 82.05ab, A & $44.49 b, \mathrm{~B}$ & $57.52 b$ \\
\hline Barley & $5.13 c, A$ & $1.35 \mathrm{~b}, \mathrm{~A}$ & $2.65 b c$ \\
\hline$\chi^{2(6)}$ & 108.46 & 73.487 & 130.31 \\
\hline$P$ & $<0.001$ & $<0.001$ & $<0.001$ \\
\hline \multicolumn{4}{|l|}{ Sources of grains } \\
\hline Farmers & 100a, A & 94.59a, A & $96.46 a$ \\
\hline Contracted farmers & $2.56 \mathrm{~b}, \mathrm{~A}$ & $6.76 \mathrm{~b}, \mathrm{~A}$ & $5.31 b c$ \\
\hline Cooperative society & $15.38 \mathrm{~b}, \mathrm{~A}$ & $4.05 \mathrm{bc}, \mathrm{B}$ & $7.96 \mathrm{bc}$ \\
\hline Imports & $7.69 \mathrm{~b}, \mathrm{~A}$ & $21.62 \mathrm{~b}, \mathrm{~A}$ & $16.81 b$ \\
\hline Inter-depot transfers & 79.49a, A & Obc, B & $27.43 b$ \\
\hline Retail brokers & $100 a, A$ & 94.59a, A & $68.14 a$ \\
\hline$\chi^{2(5)}$ & 76.09 & 185.66 & 209.14 \\
\hline$P$ & $<0.001$ & $<0.001$ & $<0.001$ \\
\hline \multicolumn{4}{|l|}{ Pre-storage practices } \\
\hline Re-dry grains before storage & $17.95 \mathrm{~b}, \mathrm{~B}$ & $47.3 \mathrm{~b}, \mathrm{~A}$ & $37.17 \mathrm{~b}$ \\
\hline Re-bag to standardize grain weight & $66.67 a, A$ & $36.49 \mathrm{~b}, \mathrm{~B}$ & $46.9 b$ \\
\hline Accept poor quality grains at lower price. & Ob, B & $37.84 \mathrm{~b}, \mathrm{~A}$ & $24.78 b$ \\
\hline Accept low quality grains for other uses & $\mathrm{Ob}, \mathrm{A}$ & $8.11 \mathrm{~b}, \mathrm{~A}$ & $5.31 \mathrm{c}$ \\
\hline Clean grains before storage & 23.08a, A & $23.38 \mathrm{~b}, \mathrm{~A}$ & $26.55 b$ \\
\hline Reject low quality grains & $97.44 a, A$ & 93.24a, A & $94.67 a$ \\
\hline$\chi 2(5)$ & 88.75 & 71.29 & 134.2 \\
\hline$P$ & $<0.001$ & $<0.001$ & $<0.001$ \\
\hline
\end{tabular}

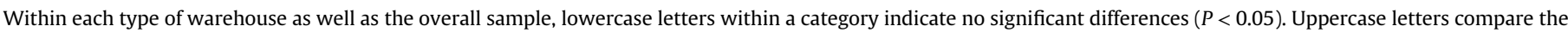
two warehouse types; same letters indicate no significant difference $(P<0.05)$.

a Public warehouses.

b Private stores.

Table 4

Parameters examined during grain purchase and the compliance to quality standards. $^{c}$

\begin{tabular}{|c|c|c|c|c|}
\hline \multirow[t]{3}{*}{ Quality parameter } & \multicolumn{4}{|c|}{ Proportion of stores (\%) } \\
\hline & \multicolumn{2}{|c|}{$\operatorname{PWs}^{\mathrm{a}}(N=39)$} & \multicolumn{2}{|c|}{$\mathrm{Ss}^{\mathrm{b}}(N=74)$} \\
\hline & Analyzed & Compliant & Analyzed & Compliant \\
\hline Moisture content & 100.0a, A & $100 a, A$ & 93.2a, A & $41.9 b, \mathrm{~B}$ \\
\hline Foreign matter & 100.0a, A & $97.4 a, A$ & 74.3ab, B & $32.9 b, \mathrm{~B}$ \\
\hline Inorganic matter & 84.6a, A & 84.6a, A & $5.4 \mathrm{c}, \mathrm{B}$ & $96.0 \mathrm{a}, \mathrm{A}$ \\
\hline Broken grains & 100.0a, A & 100a, A & $40.5 \mathrm{~b}, \mathrm{~B}$ & 73.0a, B \\
\hline Pest damaged grains & 100.0a A & $100 a, A$ & $87.8 \mathrm{a}, \mathrm{B}$ & $47.3 \mathrm{~b}, \mathrm{~B}$ \\
\hline Rotten and diseased grains & $97.4 a, A$ & 100a, A & 81.1ab, B & 59.5a, B \\
\hline Discolored grains & 100.0a, A & $100 a, A$ & 64.9ab, B & 51.1a, B \\
\hline Live insect infestation & $97.4 \mathrm{a}, \mathrm{A}$ & 97.4a, A & $86.5 a, A$ & $86.5 a$, B \\
\hline Shriveled grains & 100.0a, A & $100 a, A$ & $43.2 \mathrm{~b}, \mathrm{~B}$ & $63.5 a, B$ \\
\hline Aflatoxin & $97.4 a, A$ & 97.4a, A & $12.2 \mathrm{c}, \mathrm{B}$ & $90.5 \mathrm{abc}, \mathrm{A}$ \\
\hline$\chi 2(9)$ & 0.92 & 0.827 & 115.2 & 47.6 \\
\hline$P$ & 0.9996 & 0.9997 & $<0.001$ & $<0.001$ \\
\hline
\end{tabular}

Within each type of warehouse same lower case letters within a category indicate no significant differences at $(P<0.05)$. Uppercase letters compare the two warehouse types; same letters for columns with the same heading indicate no significant difference $(P<0.05)$.

a Public warehouses.

b Private stores.

c Kenya Bureau of Standards (KEBS).

a quarter reported mold infection, rodent damage, and aflatoxin contamination as 'very important' storage problems (Fig. 4a). Spillage and damage by birds were 'very important' problems for only $12.8 \%$ and $5.1 \%$ of the PWs. The rankings were similar in the PSs for insect damage $(\chi 2(1)=0.609, P=0.435)$, mold infection $(\chi 2(1)=0.046, P=0.830)$, rodent damage $(\chi 2(1)=3.846$, $P=0.05)$ aflatoxin contamination $(; \chi 2(1)=3.354, P=0.067)$, spillages $(\chi 2(1)=0.088, P=0.767)$, and damage by birds $(\chi 2$ $(1)=0.067, P=0.792$ )

With regard to specific pests (Fig. $4 \mathrm{~b}$ ), rodents were reported with the highest frequency followed by Sitophilus spp. and $P$. truncatus. The reporting frequencies of these three pests in the two store types were, however, not significantly different (rodents: $\left(\chi^{2}(1)=0.532, P=0.466\right.$; Sitophilus spp.: $\chi^{2}(1)=3.01, P=0.083$; P. truncatus: $\left.\chi^{2}(1)=2.971, P=0.085\right)$. Other insect pests including Tribolium spp., grain moths, and the lesser grain borer (Rhyzopertha dominica, (Fabricius)), were reported with significantly higher frequency in the PWs (Tribolium spp: $\chi^{2}(1)=4.445, P=0.035$; grain moths: $\chi^{2}(1)=7.409, P=0.006 ; R$. dominica: $\chi^{2}(1)=9.737$, $P=0.002$ ). Birds were also reported with a significantly higher frequency in PWs $\left(\chi^{2}(1)=5.585, P=0.018\right)$, whereas bruchids, which specifically attack pulses, were reported with a frequency of approximately $50 \%$ in the two store types $\left(\chi^{2}(1)=0.098\right.$, $P=0.755$ ).

\subsection{Responses to storage problems}

Table 6 shows that more stores responded to insects and rodents than to spillage and moisture. All PWs applied residual insecticides as well as fumigants to control insect pests, whereas only about two thirds of the PSs used residual insecticides, and half of the PSs used fumigants. In the overall sample, residual insecticides and fumigants were used in equal measure $\left(\chi^{2}(1)=0.390, P=0.532\right)$. The larger proportion of stores applied Actellic based insecticides and phosphine based fumigants (Table 6). All PWs used Actellic ${ }^{\circledR} 50$ EC (Pirimiphos-Methyl $500 \mathrm{~g} / \mathrm{L}$ ) to spray store surfaces and bag stacks after fumigation. Contrastingly, a significantly lower proportion of PSs $\left(\chi^{2}(1)=8.548, p=0.003\right)$ sprayed after fumigation. Moreover, 
Table 5

Methods and duration of grain storage.

\begin{tabular}{|c|c|c|c|}
\hline \multirow[t]{2}{*}{ Parameter } & \multicolumn{3}{|c|}{ Proportion of stores (\%) } \\
\hline & $\operatorname{PWs}^{\mathrm{a}}(N=39)$ & $\operatorname{PSs}^{\mathrm{b}}(N=74)$ & Overall $(N=113)$ \\
\hline \multicolumn{4}{|l|}{ Storage method } \\
\hline Jute bags & $100 a, A$ & $9.46 \mathrm{~b}, \mathrm{~B}$ & $40.7 b$ \\
\hline Woven polypropylene bags & 69.2a, B & 96.0a, A & $86.7 a$ \\
\hline Hermetic bags & Oc, A & $1.35 \mathrm{~b}, \mathrm{~A}$ & $0.88 \mathrm{~d}$ \\
\hline Silos & $28.2 \mathrm{ab}, \mathrm{A}$ & $4.05 \mathrm{~b}, \mathrm{~B}$ & $15.9 c$ \\
\hline$\chi 2(3)$ & 46.2 & 166.8 & 140.8 \\
\hline$P$ & $<0.001$ & $<0.001$ & $<0.001$ \\
\hline \multicolumn{4}{|l|}{ Duration of storage } \\
\hline less than 2 months & Ob, B & 70.27a, A & $46.02 \mathrm{a}$ \\
\hline $2-4$ months & $\mathrm{Ob}, \mathrm{A}$ & $12.16 \mathrm{~b}, \mathrm{~B}$ & $7.96 \mathrm{~b}$ \\
\hline 4-6 months & Ob, A & $5.41 \mathrm{~b}, \mathrm{~A}$ & $3.54 b$ \\
\hline $6-8$ months & $2.56 \mathrm{~b}, \mathrm{~A}$ & $8.11 \mathrm{~b}, \mathrm{~A}$ & $6.19 b$ \\
\hline $8-10$ months & $2.56 \mathrm{~b}, \mathrm{~A}$ & $\mathrm{Ob}, \mathrm{A}$ & $0.88 \mathrm{~b}$ \\
\hline $10-12$ months & $2.56 \mathrm{~b}, \mathrm{~A}$ & $1.35 \mathrm{~b}, \mathrm{~A}$ & $1.77 \mathrm{~b}$ \\
\hline More than 12 months & 92.31a, A & $2.7 \mathrm{~b}, \mathrm{~B}$ & $33.63 a$ \\
\hline$\chi^{2(6)}$ & 194.15 & 194.84 & 153.31 \\
\hline$P$ & $<0.001$ & $<0.001$ & $<0.001$ \\
\hline
\end{tabular}

Within each type of warehouse as well as the overall sample, values followed by same lowercase letters within a category are not significantly different $(P<0.05)$. Uppercase letters compare the two warehouse types; values followed by same letters are not significantly different $(P<0.05)$.

a Public warehouses.

b Private stores.
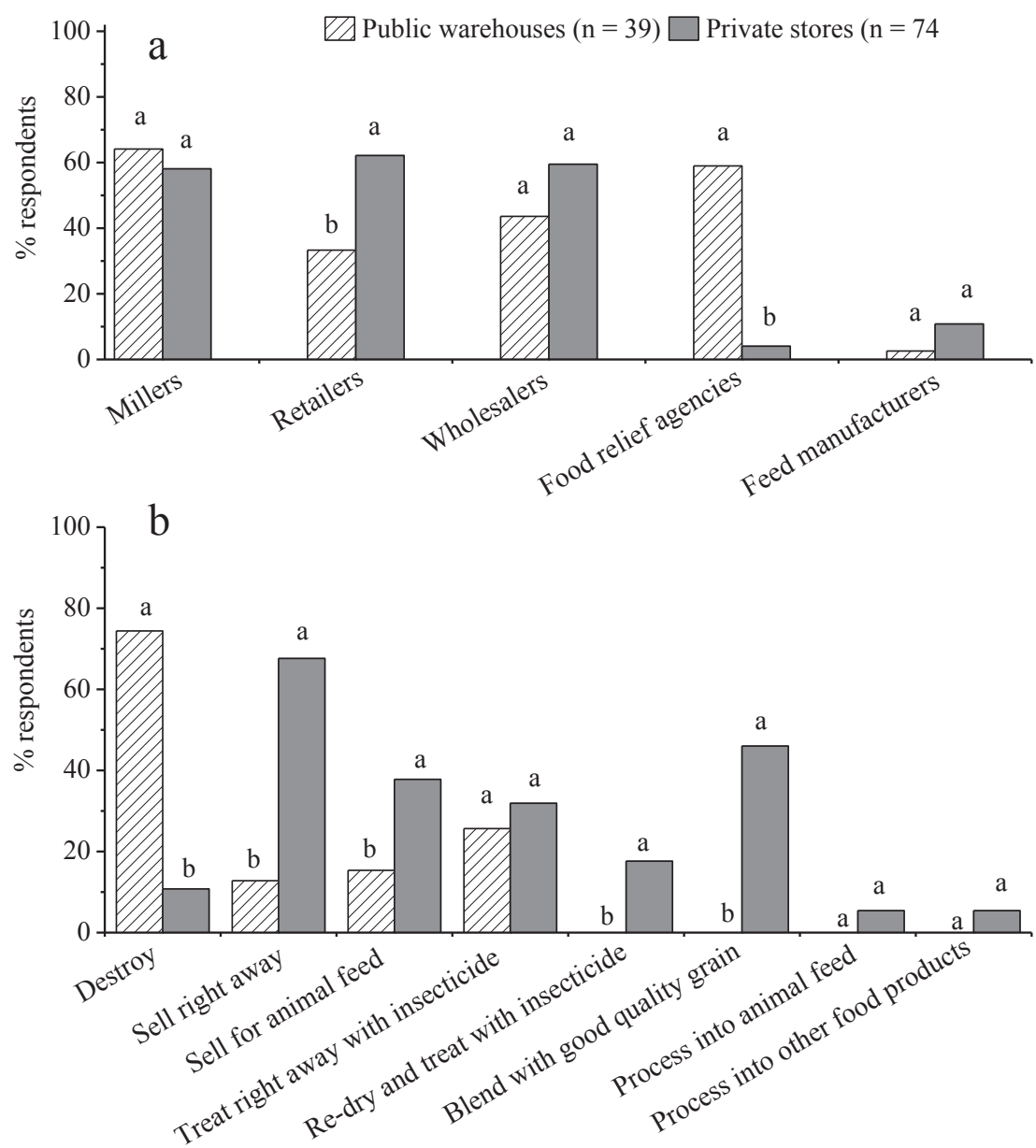

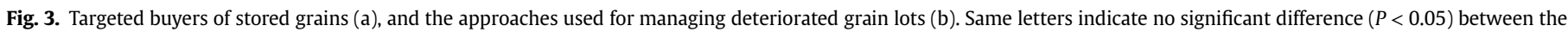
store types for a given category.

about $95 \%$ of the stores were cleaned before introducing new grain, but only half, in general, were disinfested; three quarters of PSs did not disinfest after cleaning. Almost all stores performed rodent control using rodenticides or traps. The use of rodenticides was more popular, and their use was reported with a significantly higher frequency by PWs $\left(\chi^{2}(1)=19.99, P<0.001\right)$ compared to 


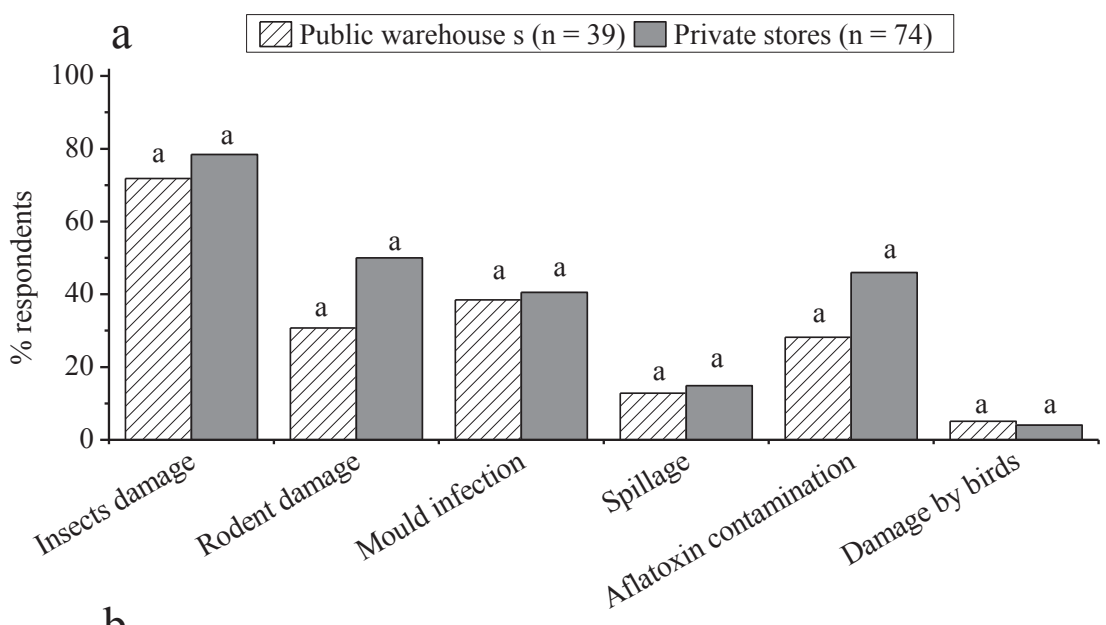

b

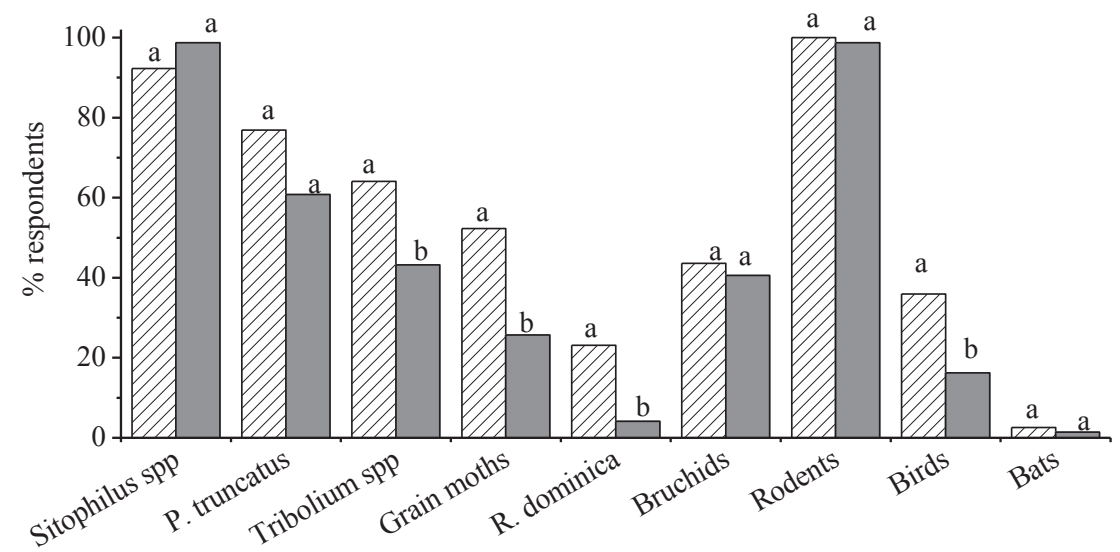

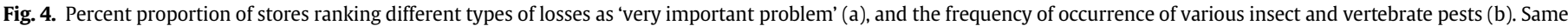
letters indicate no significant difference $(P<0.05)$ between the store types for a given category.

PSs that instead reported use of traps with a significantly higher frequency $\left(\chi^{2}(1)=7.13, P=0.008\right)$. Spillage control was performed by less than two thirds of stores, and the proportions of PWs and PSs who took measures to control spillage were not significantly different $\left(\chi^{2}(1)=1.340, P=0.247\right)$. Re-bagging was the most common method of spillage control, and was more frequently used by PWs $\left(\chi^{2}(1)=9.848, P=0.002\right)$. About two thirds of the stores also took measures to control grain moisture, mainly by drying in the sun.

In Fig. 5 the time of first application and application frequency of pesticides to control insect pests are presented. The majority of PWs treated the grain immediately after close of purchase (Fig. 5a). Contrastingly, the time of first application of insecticides by PSs varied, but a significantly higher proportion relied on infestation reports, and thus treated the grain when infestation was noticed $\left(\chi^{2}\right.$ $(1)=8.516, P=0.004)$. All PWs applied residual insecticides and fumigants routinely after every three months, respectively (Fig. $5 \mathrm{~b}$ and c), whereas majority of PSs applied only once or when infestation was noticed, as informed by infestation reports.

\subsection{Magnitude of losses}

The magnitudes of perceived storage losses are presented in Table 7. Only losses of maize have been reported as maize was the sole commodity stocked by all stores at the time of the study. Total losses in PWs and PSs were not significantly different $(Z=-1.387$, $P=0.166)$. In addition, the losses caused by insects $(Z=0.811$, $P=0.417)$, rodents $(Z=0.234, P=0.815)$ and spillage $(Z=-1.708$, $P=0.088$ ) did not differ significantly in the two storage systems. However, losses arising from moisture loss, mold infection and attack by birds were significantly higher in the PSs (moisture loss: $Z=-2.024, P=0.043$; molds infection: $Z=-3.328, P=0.002$; attack by birds: $Z=3.164, P=0.001$ ).

\subsection{Factors contributing to storage losses}

The general linear model approach was used to estimate the coefficients of the fractional logit model (FLM). Results indicate a general fit of the model, with a deviance $(D)$ statistic of 7.245 (Table 8). The deviance statistic was used because it is approximate for a small sample as in the case of this study. It compares the values predicted by the fitted model and those predicted by the most complete model that can fit the data. Hence, the smaller the deviance, the better fitted is the estimated model. This statistic compares asymptotically to the $\chi^{2}$ distribution. The $D$ statistic is not significantly different from zero and hence we conclude that the model fits the collected data and gave an inferential validity to the obtained model estimates. Table 8 summarizes the results of the model estimates and the marginal effects as well. The marginal effect measures the extent to which a unit change in the 
Table 6

Control of insects, rodents, spillages and grain moisture during storage.

\begin{tabular}{|c|c|c|c|}
\hline \multirow[t]{2}{*}{ Parameter } & \multicolumn{3}{|c|}{ Proportion of stores (\%) } \\
\hline & $\operatorname{PWs}^{\mathrm{a}}(N=39)$ & $\operatorname{PSs}^{\mathrm{b}}(N=74)$ & Overall $(N=113)$ \\
\hline Insect control & $100.0 \mathrm{~A}$ & $81.1 \mathrm{~B}$ & 87.6 \\
\hline Use residual insecticides & $100.0 \mathrm{~A}$ & $63.5 \mathrm{~B}$ & 76.1 \\
\hline Actellic Super ${ }^{C}$ & 100.0a, A & $52.8 \mathrm{a}, \mathrm{B}$ & 71.7a \\
\hline Skanna super ${ }^{\mathrm{d}}$ & $0.0 \mathrm{~b}, \mathrm{~A}$ & $6.8 \mathrm{~b}, \mathrm{~A}$ & $4.4 \mathrm{~b}$ \\
\hline$\chi^{2}(1)$ & 39 & 28.2 & 66.2 \\
\hline$P$-value & $<0.001$ & $<0.001$ & $<0.001$ \\
\hline Use fumigation & $100.0 \mathrm{~A}$ & $52.7 \mathrm{~B}$ & 69.0 \\
\hline Phosphine based & 97.4a, A & 52.7a, B & $68.1 \mathrm{a}$ \\
\hline Methyl bromide & $5.1 \mathrm{~b}, \mathrm{~A}$ & $0.0 \mathrm{~b}, \mathrm{~B}$ & $1.8 \mathrm{~b}$ \\
\hline$\chi^{2}(1)$ & 83.6 & 52.7 & 62.9 \\
\hline$P$ & $<0.001$ & $<0.001$ & $<0.001$ \\
\hline Clean warehouse & $100 \mathrm{~A}$ & 91.9B & 94.7 \\
\hline Clean and disinfect store & $97.4 \mathrm{a}, \mathrm{A}$ & 25.7b, B & $50.4 \mathrm{a}$ \\
\hline Clean and do not disinfect store & $2.6 \mathrm{~b}, \mathrm{~B}$ & $66.2 \mathrm{a}, \mathrm{A}$ & $44.3 \mathrm{a}$ \\
\hline$\chi^{2}(1)$ & 35.1 & 13.2 & 0.5 \\
\hline$P$ & 0.001 & 0.001 & 0.498 \\
\hline Rodent control & $97.4 \mathrm{~A}$ & $86.5 \mathrm{~A}$ & 90.3 \\
\hline Use rodenticides & 92.3a, A & 50.0a, B & $64.6 a$ \\
\hline Use cat & $0.0 \mathrm{~b}, \mathrm{~A}$ & $8.1 \mathrm{~b}, \mathrm{~A}$ & $5.3 \mathrm{c}$ \\
\hline Use trap & $5.1 \mathrm{~b}, \mathrm{~A}$ & 25.7a, B & $18.6 \mathrm{~b}$ \\
\hline$\chi^{2(2)}$ & 98.8 & 46.6 & 125.8 \\
\hline$P$ & 0.001 & 0.001 & 0.001 \\
\hline Spillages control & $69.3 \mathrm{~A}$ & $58.1 \mathrm{~A}$ & 62.0 \\
\hline Re-bagging & 61.6a, A & $36.5 a, B$ & $34.5 \mathrm{a}$ \\
\hline Sewing torn bags & $7.7 \mathrm{~b}, \mathrm{~A}$ & $17.6 \mathrm{~b}, \mathrm{~A}$ & $14.2 \mathrm{~b}$ \\
\hline Careful handling ${ }^{\mathrm{e}}$ & $0.0 \mathrm{c}, \mathrm{A}$ & $4.1 \mathrm{c}, \mathrm{A}$ & $2.7 \mathrm{~b}$ \\
\hline$\chi 2(2)$ & 105.2 & 15.1 & 35.5 \\
\hline$P$ & 0.001 & 0.001 & 0.001 \\
\hline Moisture control & $66.7 \mathrm{~A}$ & $62.2 \mathrm{~A}$ & 63.7 \\
\hline Sun-drying & 53.9a, A & 58.1a, A & $56.6 \mathrm{a}$ \\
\hline Mechanical drying & $12.8 \mathrm{~b}, \mathrm{~A}$ & $4.1 \mathrm{~b}, \mathrm{~A}$ & $7.1 \mathrm{~b}$ \\
\hline$\chi^{2}(1)$ & 9.9 & 34.8 & 43.6 \\
\hline$P$ & 0.001 & 0.001 & 0.001 \\
\hline
\end{tabular}

Within each type of warehouse as well as the overall sample, values followed by same lowercase letters within a category are not significantly different $(P<0.05)$. Uppercase

letters compare the two warehouse types; same letters indicate no significant difference $(P<0.05)$.

a Public warehouses.

b Private stores.

c Pirimiphos-methyl (1.6 g/100 g) + Permethrin (0.3 g/100 g).

d Malathion $(2 \mathrm{~g} / 100 \mathrm{~g})+$ Permethrin $(0.3 \mathrm{~g} / 100 \mathrm{~g})$.

e Stores implement guidelines for proper bag handling.

explanatory variable would influence total storage losses, with all other factors held constant. Storage losses were positively influenced by the use of polypropylene bags; use of KEBS standards as criteria for grain storage; use of residual insecticides for pest control; relying on infestation reports for application of insecticides, buying low quality grain, recycling of old bags, and selling to local retailers. Additionally, storing maize for less than 2 months, drying grains before storage, cleaning grain before storage and applying pesticides in the first month of storage or after close of purchase were associated with lower losses. Stores or warehouses that stored grains from imports or inter-depot transfers were likely to incur lower losses, as was also the case with stores that aggregated the grain before storage or being sold to millers. Results of marginal effects analysis show that off-farm stores located in moist transitional, moist mid-altitude and dry mid-altitude zones experience up to $5.7 \%, 8.7 \%$, and $7.6 \%$ higher losses, respectively, compared to those located in the lowland tropical zone which had the lowest magnitude of losses. Moreover, using polypropylene bags is associated with an increase of losses by $13.6 \%$. Off-farm grain stores that rely on infestation reports to initiate application of pesticides, use residual insecticides, recycle old sacks for bagging of grain, and sell to local retailers are likely to have their losses higher by $21.7 \%, 9.3 \%$, $13.5 \%$ and $8.3 \%$, respectively, compared to the use of their alternatives.

\section{Discussion}

\subsection{Characteristics of stores and storage practices}

Off-farm stores owned by private actors keep grains for shorter durations for commercial reasons, while the public warehouses store for periods exceeding 12 months. The short storage duration coupled with high cost of constructing a proper storage structure may explain why the majority of PSs are not purpose-built for grain storage. Ordinarily, economically significant losses, e.g. by insects, are manifested after 3-4 months of storage (Henckes, 1994). However, structures that are not designed for grain storage may fail to offer sufficient grain protection against abiotic and biotic factors, and may not facilitate easy cleaning and disinfestation (Gwinner et al., 1996). Insects also multiply more profusely in storage spaces that promote warm humid conditions such as those made of corrugated iron sheets (Gwinner et al., 1996). Thus poorly constructed storage structures might partly explain why a higher proportion of PSs experience storage problems related to insects, rodents and molds despite the shorter storage periods.

Both PWs and PSs obtain grains from the same sources except that PWs also source from inter-depot transfers and cooperatives. For the PWs, inter-depot transfers create space for newly harvested crops and minimize cross infestation. The practices of re-drying 

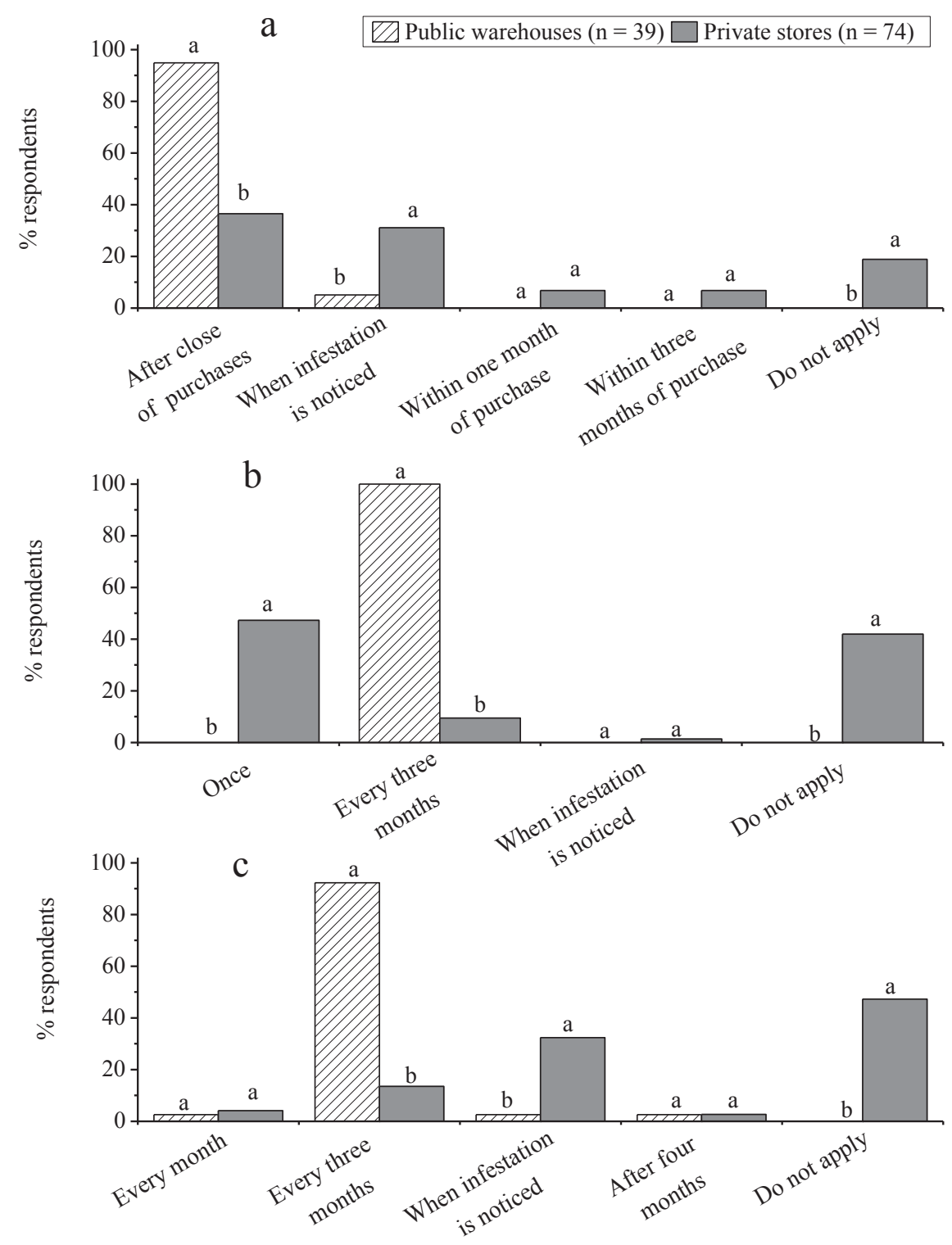

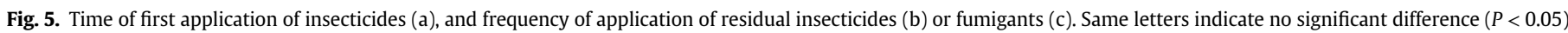
between the store types for a given category.

Table 7

Magnitude of perceived storage losses for maize.

\begin{tabular}{|c|c|c|c|c|c|c|c|}
\hline & \multicolumn{7}{|c|}{ Perceived weight losses (\%) } \\
\hline & Insects & Rodents & Molds & Spillages & Birds & Moisture & Total \\
\hline $\mathrm{PWs}^{\mathrm{a}}(N=39)$ & $7.0 \pm 1.6 a, A$ & $4 \pm 0.6 \mathrm{~b}, \mathrm{~A}$ & $0.0 \pm 0.0 \mathrm{~d}, \mathrm{~B}$ & $0.5 \pm 0.2 \mathrm{c}, \mathrm{A}$ & $0.2 \pm 0.1 \mathrm{~cd}, \mathrm{~A}$ & $2.4 \pm 0.8 \mathrm{~b}, \mathrm{~B}$ & $11.0 \pm 2.1 \mathrm{~A}$ \\
\hline $\operatorname{PSs}^{\mathrm{b}}(N=74)$ & $7.3 \pm 1.3 \mathrm{~b}, \mathrm{~A}$ & $7 \pm 0.8 \mathrm{a}, \mathrm{A}$ & $8.7 \pm 3.1 b, A$ & $0.5 \pm 0.1 \mathrm{a}, \mathrm{A}$ & $0.0 \pm 0.0 \mathrm{a}, \mathrm{B}$ & $3.9 \pm 0.6 b c, A$ & $21.0 \pm 3.2 \mathrm{~A}$ \\
\hline Average & $7.2 \pm 1.0 \mathrm{a}$ & $2.0 \pm 0.5 \mathrm{ab}$ & $5.7 \pm 2.1 \mathrm{e}$ & $0.5 \pm 0.0 \mathrm{~cd}$ & $0.1 \pm 0.04 d$ & $3.4 \pm 0.5 b c$ & $17.6 \pm 2.3$ \\
\hline
\end{tabular}

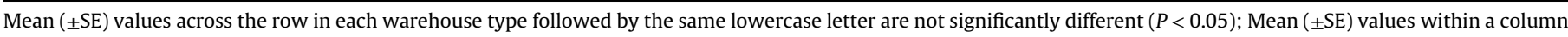
followed by the same uppercase letters are not significantly different $(P<0.05)$.

a Public warehouses.

b Private stores.

grains before storage which is common in PSs could be related to lack of equipment to ascertain grain moisture at point of purchase or a tendency to purchase high moisture grain offered at lower prices by farmers who are pushed to sell early in the harvest season so as to raise urgent household incomes. It was observed that many PSs performed sun-drying in open yards. According to Kaaya and
Kyamuhangi (2010), sun-drying of grain on bare ground or spread out tarpaulins predisposes it to mold contaminations which persist during storage. This observation by Kaaya and Kyamuhangi (2010) agrees well with our finding that storage losses due to molds are significantly higher in the PSs. Moreover, it was found that less than half of the PSs comply with the locally recommended moisture 
Table 8

Generalized linear model and marginal effects of factors influencing storage losses.

\begin{tabular}{|c|c|c|c|c|}
\hline \multirow[t]{2}{*}{ Factor } & \multicolumn{2}{|l|}{ Model } & \multicolumn{2}{|c|}{ Marginal effects } \\
\hline & Coefficient. & s.e. & Coefficient & s.e. \\
\hline \multicolumn{5}{|l|}{ Agro-ecological zones (LLT ${ }^{\mathrm{a}}=$ base category) } \\
\hline Highland tropics & 0.219 & 0.413 & 0.017 & 0.032 \\
\hline Moist transitional zone & $0.727^{* *}$ & 0.318 & $0.057^{* *}$ & 0.026 \\
\hline Moist mid-altitude & $1.110^{* *}$ & 0.525 & $0.087^{* *}$ & 0.041 \\
\hline Dry mid-altitude & $0.968^{* * *}$ & 0.306 & $0.076^{* * *}$ & 0.025 \\
\hline Dry Transitional & -0.517 & 0.397 & -0.041 & 0.031 \\
\hline \multicolumn{5}{|l|}{ Storage factors } \\
\hline Warehouse type (dummy = 1 if PW; 0 if PS) & -0.218 & 0.65 & -0.017 & 0.051 \\
\hline Import grains & $-1.187^{* * *}$ & 0.342 & $-0.093^{* * *}$ & 0.028 \\
\hline Inter-depot transfer & $-1.311^{* * *}$ & 0.436 & $-0.103^{* * *}$ & 0.034 \\
\hline Aggregate grains & $-1.309^{* * *}$ & 0.339 & $-0.103^{* * *}$ & 0.027 \\
\hline Use jute bags & 0.617 & 0.458 & 0.048 & 0.035 \\
\hline Use polypropylene bags & $1.734^{* * *}$ & 0.476 & $0.136^{* * *}$ & 0.038 \\
\hline Use KEBS standards & $1.779^{* * *}$ & 0.669 & $0.140^{* * *}$ & 0.053 \\
\hline Buy low quality grain & $0.702^{* * *}$ & 0.265 & $0.055^{* * *}$ & 0.021 \\
\hline Store for $<2$ months & $-0.866^{* * *}$ & 0.325 & $-0.068^{* * *}$ & 0.026 \\
\hline Store for $>12$ months & 0.273 & 0.435 & 0.021 & 0.035 \\
\hline Dry grains before storage & $-1.003^{* * *}$ & 0.329 & $-0.079^{* * *}$ & 0.026 \\
\hline Clean grains before storage & $-0.569^{* *}$ & 0.315 & $-0.045^{* *}$ & 0.025 \\
\hline Use residual pesticides & $1.179^{* * *}$ & 0.33 & $0.093^{* * *}$ & 0.027 \\
\hline Rely on infestation reports for treatment & $2.766^{* * *}$ & 0.529 & $0.217^{* * *}$ & 0.04 \\
\hline Apply pesticides within first month & $-1.244^{* * *}$ & 0.464 & $-0.098^{* * *}$ & 0.036 \\
\hline Apply pesticides after close of purchases & $-0.994^{* *}$ & 0.415 & $-0.078^{* *}$ & 0.034 \\
\hline Reuse old storage bags & $1.716^{* * *}$ & 0.362 & $0.135^{* * *}$ & 0.029 \\
\hline Sell to local retailers & $1.056^{* * *}$ & 0.323 & $0.083^{* * *}$ & 0.026 \\
\hline Sell to millers & $-0.648^{* * *}$ & 0.236 & $-0.051^{* * *}$ & 0.019 \\
\hline Trained on postharvest (dummy $=1$ if trained; 0 if not trained) & 0.007 & 0.274 & 0.001 & 0.021 \\
\hline Intercept & $-5.286^{* * *}$ & 1.018 & & \\
\hline Deviance $(D)$ & 7.245 & & & \\
\hline Pearson & 7.951 & & & \\
\hline Akaike information criterion (AIC) & 0.835 & & & \\
\hline Bayesian information criterion (BIC) & -413.49 & & & \\
\hline
\end{tabular}

${ }^{\text {a }}$ Lowland tropical zone; ${ }^{*} P \leq 0.1 ;{ }^{* *} P \leq 0.05 ;{ }^{* * *} P \leq 0.01$.

standards for safe storage. With regard to drying practices and the contaminations that may arise, it is also of interest that inorganic contaminants and aflatoxin were among the least frequently tested quality parameters by PSs, which points to lack of strict surveillance and enforcement of standards.

Bag storage was the most widespread storage technique and this can be attributed to the flexibility that bags offer as they can be moved easily for inspection and sale (Hodges, 2004). The WPP bags in particular are cheaper and readily available, but also convenient for frequent and dynamic trading activities, which explain their popularity among PSs. However, WPP may predispose the grain to quality deterioration due to accumulation of heat and moisture from grain respiration, and for this reason, jute bags are recommended for long-term storage although they are easily damaged by rodents and birds leading to higher losses from spillage and contaminations (Hodges and Farrell, 2004). The use of bulk storage systems was uncommon, and this could be attributed to the high costs of construction, maintenance and repair, and high capital required to stock grains to capacity (Hodges et al., 2011).

Off-farm stores are important market intermediaries that supply grain to millers, wholesalers, retailers, food relief agencies and feed manufacturers as revealed by findings of the present study. There are no distinct markets for PSs and PWs except that a bigger proportion of PSs sell to retailers while a greater proportion of the PWs sell to food relief agencies. This difference is explained by logistical and functional reasons. The PSs are commercial entities whose operations are influenced by market dynamics, whereas the PWs endeavour to maintain strategic reserves. It was however of interest to understand how both storage systems handle deteriorated grain within the context of their role as market intermediaries, as this has impact on availability of safe food for consumers. A majority of PWs destroyed the deteriorated grains but the PSs did not do so. This is probably because storage durations in PSs are shorter, and by inference, extreme deteriorations may be less frequent. However, the finding that many off-farm stores do not destroy deteriorated grain implies that undesirable substances eventually find their way into food chains. This is a concern considering that a significant proportion of the PSs would accept low quality grain if sold at low prices and do not examine the grain for all important quality parameters. In a cross sectional survey that assessed sources of contamination during a severe aflatoxicosis outbreak in Kenya, Lewis et al. (2005) also concluded that the grain distribution system played a role in sustaining aflatoxin exposure.

\subsection{Storage problems and magnitude of losses}

Insects, molds and rodents were the most important storage problems causing physical losses. The overall perceived maize storage losses in this study (17.6\%) compared closely with the loss magnitude of (15.5\%) reported for on-farm stores in Kenya (EdohOgnakossan et al., 2016). Insects including P. truncatus and Sitophilus spp. are the most frequent insect pests in grain stores (Holst et al., 2000). The observation that Sitophilus spp were more frequently reported than $P$. truncatus is explained by the diversity and seasonal nature of the pests. According to Birkinshaw et al. (2002) and Hodges (2002) Sitophilus spp are widespread, and in most seasons and years, a high risk of their attack exists whereas $P$. truncatus outbreaks are sporadic for various biological and ecological reasons. The presence of less frequent pests such as the lesser grain borer ( $R$. dominica) and grain moths may be linked 
partly to storage practices and partly to store hygiene. $R$. dominica commonly attacks smaller grains such as rice, millet and wheat (Golob, 2009) whereas moths such as S. cerealella, the most common in grain stores, is frequently associated with cob maize, wheat and sorghum soon after harvest (Golob, 2009) and the presence in shelled maize stores may be linked to stocking of poorly cleaned grains. Other moths include the tropical warehouse moth (Ephestia cautella, Walker) and Indian meal moth (Ploidia interpunctella, Hubner). The presence of Tribolium spp is an indicator of advanced grain damage by the primary pests (Golob, 2009), and implied storage over several months without effective pest control in the PWs and some PSs. The losses caused by insects also compared closely with those reported in Kenyan on-farm stores (EdohOgnakossan). Losses caused by $P$. truncatus on maize can exceed $30 \%$ dry weight within 3-6 months if no interventions are applied (Nansen and Meikle, 2000). Sitophilus spp. also cause devastating losses in poorly managed storage structures (Ng'ang'an et al., 2016a,b). Generally, such high loss magnitudes were not reported because various interventions including treatment with residual insecticides and fumigants were reportedly implemented in the stores.

Molds were an important cause of storage losses particularly in the PSs. Molds of the genera Aspergillus, Fusarium and Pencillium, among others, may be found colonizing a variety of substrates in stores under a wide range of environmental conditions (Ng'ang'an et al., 2016a,b). Grain sourcing, and the pre-storage and storage practices possibly encouraged mold infections in PSs. Longer storage periods are linked to high mold incidence (Hell et al., 2000; Kaaya and Kyamuhangire, 2006) whereas poorly ventilated stores are associated with humid and warm conditions that favor mold growth (Hell et al., 2000). A myriad of other practices such as storing inadequately dried grain, failure to separate chaff, moldy and broken grains, re-use of old bags, blending of good with poor quality grains, drying grain on bare ground, insect infestations and poor store hygiene also support mold growth (Ng'ang'an et al., 2016a,b). An extra concern regarding mold contamination is the ability of some species to produce toxic metabolites (Lewis et al., 2005; Wagacha and Muthomi, 2008).

Rodents were identified as a storage problem in nearly all PWs and PSs. This was probably encouraged by inadequate structures which did not stop migration from habitation environments such as surrounding fields and waste dumping sites (Panti-May et al., 2012). Poor store hygiene may also attract rodents. The contribution of rodents to total perceived losses approximated 12\%. EdohOgnakossan et al. (2016) reported rodents to be the second most important cause of storage losses after insects in Kenya on-farm storage systems where rodents contributed $30-43 \%$ of the total losses. Thus, in off-farm stores, rodents cause less than half the losses they cause in off-farm stores. Nonetheless, rodents are also associated with loss quality such contamination with faeces, hair and urine which lowers market value. Rodents are also well-known vectors for diseases of public health concern (Cao et al., 2002), further cause damage to storage material and equipment (Gwinner et al., 1996), and cause germination failure of seeds if intended for planting.

Moisture loss contributed about 20\% to the total storage losses. Although loss of moisture does not represent actual food loss, it is of significance to off-farm stores because it constitutes loss of sellable weight. The higher weight loss reported for PSs as compared to PWs is possibly associated with purchasing and storing improperly dried grain. The weight loss in PWs is probably due to the long storage periods. Moreover, condition of the store could contribute to excessive moisture loss. A number of stores were corrugated iron halls and the majority of stores had corrugated iron roofs. Corrugated iron sheet walls or roofs encourage overheating especially if they lack ventilation openings that regulate storage temperatures (Gwinner et al., 1996).

\subsection{Factors influencing the magnitude of losses}

Location of store and grain management factors including grain sources, pre-storage and storage practices, and target markets influenced the magnitude of losses experienced in off-farm stores. From marginal effects analysis, the agro-ecological conditions of the moist transitional, moist mid-altitude, and dry mid-altitude zones favor higher losses (margins 5.7-8.7\%) particularly from insects and molds. These regions have medium to high potential for maize production. Huge harvests might put pressure on existing storage facilities leading to ineffective protection. Obtaining grains from imports and inter-depot transfers (common in PWs) may result in lower magnitude of losses by $9.3 \%$ and $10 \%$. This is explained by better pest control protocols in that imported grain undergoes strict phyto-sanitary checks at points of entry, whereas grain destined for inter-depot transfer is fumigated in the originating warehouses and immediately after storage in the destination stores. Adherence to local quality standards during grain purchase contributes to higher magnitudes of perceived losses by a margin of $14 \%$. The majority of stores that complied with KEBS standards were the PWs. A sizeable proportion of the PSs also complied with KEBS standards. These stores probably also continue to apply the standards during storage, which would translate to higher perceived losses when the deteriorated lots are discarded. On another level, this observation suggests that many off-farm stores especially the PSs do not have sufficient incentives to maintain good quality. Indeed, the marginal effects analysis also shows that selling to local retailers is associated with higher losses (marginal effect of $8.3 \%$ ), whereas selling to millers would be associated with lower loss magnitudes (marginal effect of 5.1\%). Millers, who are bigger buyers than local retailers, are more mindful of quality, and are able to pay premium prices, thus enabling stores that supply them to invest in more efficient storage. Nonetheless, strict standards may aggravate losses if there are no mechanisms to absorb sub-standard products into alternative uses (Naziri et al., 2014). Sorting and grading losses are often incurred in markets that thrive on quality (Affognon et al., 2015). Products regarded unfit at one market level could be diverted to alternative uses thereby minimizing the overall impact of losses.

The practices of cleaning and drying the grain before storage may result in lower losses by margins of $4.5 \%$ and $7.9 \%$, respectively, because they help in reducing mold and pest incidence in stored grain lots (Golob, 2009; Gwinner et al., 1996; Lale, 1998). Stores that purchase low quality, e.g. poorly dried and cleaned grain for storage, are likely to experience higher losses by a margin of $5.5 \%$ as compared to those that do not. Similarly, those that use woven polypropylene bags or re-use old bags would experience higher losses by margins of $13.6 \%$ and $13.5 \%$ as compared to use of their alternatives, respectively. These practices were common particularly among the PSs, and relate to the lack of good knowledge on best practices for effective grain storage as revealed by findings of this study.

It was of interest that stores using residual insecticides would experience more losses by $9.3 \%$ compared to the alternative (fumigation). Actellic Super Dust (Pirimiphos-methyl (1.6 g/ $100 \mathrm{~g})+$ Permethrin $(0.3 \mathrm{~g} / 100 \mathrm{~g}))$ and Skana Super (Malathion $(2 \mathrm{~g} / 100 \mathrm{~g})+$ Permethrin $(0.3 \mathrm{~g} / 100 \mathrm{~g}))$ were the commonly used residual insecticides. Elsewhere, other researchers also reported the limited efficacy residual insecticides for stored cereal and legume grains protection in East Africa (Mutungi et al., 2014; Njoroge et al., 2014). The progressive loss of insecticidal potency (Denloye et al., 2008), possible adulteration by unscrupulous 
traders (Golob and Hanks, 1990), inappropriate application (Mutambuki and Ngatia, 2012), and resistance by some strains (Odeyemi et al., 2010) may explain the present observation. Moreover, a number of studies have shown that residual insecticides (WP and EC formulations) applied as sanitizers on stores' surfaces made of brick, concrete or wood can lose the knockdown effect on the target pests due to the adsorbent nature of such surfaces (Hodges and Dales, 1991; Jankov et al., 2013).

The marginal effects analysis also reveals that stores that relied on infestation reports so as to schedule application of insecticides would incur $21.7 \%$ higher losses. In fact, stores that apply insecticides immediately after close of purchases or within the first month of storage would incur lower losses by $7.8 \%$ and $9.8 \%$, respectively. At farm level where grain is intended for home use, Henckes (1994) showed that application of pesticide is not economical if storage is not to exceed 3-4 months, since grain damage and weight loss would still be below the economic threshold. However, in off-farm stores early treatment appears to be important because any damage and weight loss has a direct impact on returns (Compton et al., 1998). Moreover, off-farm stores receive grain from varied sources, and infestations that are undetectable by visual inspection may be advanced in some grain lots making effective control difficult (Fleurat-Lessard et al., 2006). Golob and Hanks (1990) recognised the importance of prophylactic application of pesticides for successful pest control in stored grain. In the context of the present findings, early detection of infestations would be helpful in reducing the magnitude of losses because it would allow prompt treatment of grains. For example, acoustic detection is a promising method for detecting insect larvae inside stored product grain kernels (Njoroge et al., 2016; Kiobia et al., 2015; Mankin et al., 2011).

Overall, this study demonstrates that good grain storage is a challenge in off-farm stores in Kenya because best practices and good storage protection are not followed. The privately owned stores contend with the facilities they can cheaply find or construct, and the level of training is low, while the government owned warehouses store for exceedingly long periods. Since these findings are self-reported by facility owners or managers themselves, they should help develop loss reduction strategies that are evidence based. Training is needed to build the capacity of privately owned stores while frequent surveillance and enforcement of standards needs to be strengthened. In this regard, development of commercially workable standards is equally important.

\section{Acknowledgements}

We gratefully acknowledge the financial support for this research by the following organizations and agencies: the RELOAD Project funded by BMZ/GIZ (Federal Ministry for Economic Cooperation and Development/German Corporation for International Cooperation) through Grant Number 81161243); UK Aid from the UK Government; Swedish International Development Cooperation Agency (Sida); the Swiss Agency for Development and Cooperation (SDC); and the Kenyan Government. The views expressed herein do not necessarily reflect the official opinion of the donors.

\section{References}

Abate, T., Van Huis, A., Ampofo, J.K., 2000. Pest management in traditional agriculture: an African perspective. Annu. Rev. Entomol. 45, 631-659.

Adejumo, B.A., Raji, A.O., 2007. Technical appraisal of grain storage systems in the Nigerian Sudan Savannah. Agric. Eng. Int. CIGRE J. IX. Invited Overview No. 11 September 2007.

Affognon, H., Mutungi, C., Sanginga, P., Borgemeister, C., 2015. Unpacking postharvest losses in sub-Saharan Africa: a Meta-analysis. World Dev. 66, 49-68.

Agnew, J., Balduzzi, P., Sunden, A., 1995. Portfolio choice and trading in a large 401 (k) plan. Am. Econ. Rev. 93, 11-23.
APHILIS, 2016. African Postharvest Losses Information System. www.aphlis.net (Accessed 30 September 2016).

Bastos, J.A., 2010. Forecasting bank loans loss-given-default. J. Bank. Financ. 34, $2510-2517$.

Benhalima, H., Chaudhry, M.Q., Mills, K.A., Price, N.R., 2004. Phosphine resistance in stored-product insects collected from various grain storage facilities in Morocco. J. Stored Prod. Res. 40, 241-249.

Birkinshaw, L.A., Hodges, R.J., Addo, S., Riwa, W., 2002. Can 'bad' years for damage by Prostephanus truncatus be predicted? Crop Prot. 21, 783-791.

Cao, D., Pimentel, D., Hart, K., 2002. Post-harvest food losses (vertebrates). In: Pimentel, D. (Ed.), Encyclopedia of Pest Management. Marcel Dekker, pp. 648-649.

Carpenter, J.F., Stanton, R., Wallace, N., 2009. Estimation of Employee Stock Option Exercise Rates and Firm Cost. Finance Working Paper Available via DIALOG. http://archive.nyu.edu/handle/2451/29546.

Chaudhry, M.Q. 1997. A review of the mechanisms involved in the action of phosphine as an insecticide and phosphine resistance in stored-product insects. Pest Manag. Sci. 14, 213-228.

Compton, J.A.F., Floyd, S., Magrath, P.A., Addo, S., Gbedevi, S.R., Agbo, B., Bokor, G., Amekupe, S., Motey, Z., Penni, H., Kumi, S., 1998. Involving grain traders in determining the effect of postharvest insect damage on the price of maize in African markets. Crop Prot. 17, 483-489.

De Groote, H., 2002. Maize yield losses from stemborers in Kenya. Insect Sci. its Appl. 22, 89-96.

Denloye, A.A., Tesilim, K.O., Negbenebor, H., Makanjuola, W.A., 2008. Assessment of the efficacy of Actellic and Sumithion in protecting grains from insect infestation during storage. J. Entomol. 5, 24-30.

Edoh-Ognakossan, K., Affognon, H.D., Mutungi, C., Sila, D.N., Soul-Kifouly, G.M., Owino, O.W., 2016. On-farm maize storage systems and rodent postharvest losses in six maize growing agro-ecological zones of Kenya. Food Secur. 8, 1169-1189.

FAO, M.A.F.A.P., 2013. Analysis of Incentives and Disincentives for Maize in Kenya, p. 3. February 2013.

FAOSTAT, 2016. International Agricultural Statistics: Food Balance Sheet. Italy, FAO, Rome.

Fleurat-Lessard, F., Tomasini, B., Kostine, L., Fuzeau, B., 2006. Acoustic detection and automatic identification of insect stage activity in grain bulks by noise spectra processing through classification algorithms. $9^{\text {th }}$ International Working Conference on Stored Product Protection Campinas. Brazil.

Golob, P., 2009. Agricultural and food engineering training and resource materials. In: Boxall, R. Gallat, S. (Eds.), On-farm Post-Harvest Management of Food Grains: a Manual for Extension Workers with Special Reference to Africa. Rome, vol. 2. Food and Agriculture Organization of the United Nations, pp. 13-17.

Golob, P., Hanks, C., 1990. Protection of farm stored maize against infestation by Prostephanus trancatus (Horn) and Sitophilus species in Tanzania. J. Stored Prod. Res. 26, 187-198.

Golob, P., Hodges, R.J., 1982. Study on an Outbreak of Prostephanus Truncatus (Horn) in Tanzania. Report G162. Tropical Development and Research Institute, London.

Grippa, P., Iannotti, S., Leandri, F., 2005. Recovery rates in the banking: stylized facts emerging from Italian experience. In: Altman, E.I., Resti, A., Sironi, A. (Eds.), The Next Challenge in Credit Risk Management. Riskbooks, London, pp. 121-141.

Gwinner, J., Harnisch, R., Mueck, O., 1996. Manual on the Prevention of Post-harvest Grain Losses. GTZ, Germany, p. 167.

Hassan, R., Njoroge, K., Otsyula, R., Laboso, A., 1998. Adoption patterns and performance of improved maize in Kenya. In: Hassan, R. (Ed.), Maize Technology Development and Transfer. A GIS Application for Research Planning in Kenya. CAB International, Oxon, UK, pp. 107-136.

Hell, K., Cardwell, K.F., Setamou, M., Poehling, H.-M., 2000. The influence of storage practices on aflatoxin contamination in maize in four agro-ecological zones of Benin, West Africa. J. Stored Prod. Res. 36, 365-382.

Henckes, C., 1994. Dividing the harvest: An approach to integrated pest management in family stores in Africa. In E. Highley, E. J. Wright, H. J. Banks, \& B. R. Champ (Eds.), Proceedings of the 6th international working conference on stored product protection held on 17-18th April 1994, in Canberra, Australia (Vol. 2 pp. 925-928)

Hodges, R.J., 2002. Detection and monitoring of the larger grain borer, Prostephanus truncatus (Horn) (Coleoptera: Bostrichidae). Integr. Pest Manag. Rev. 7, 223-243.

Hodges, R., 2004. Crop post-harvest: science and technology. In: Hodges, R., Farrell, G. (Eds.), Durable Case Studies in the Handling and Storage of Durable Commodities, vol. 2. Blackwell Publishing Company.

Hodges, R.J., Dales, M.J., 1991. Report on an Investigation of Insecticide Persistence on Grain Store Surfaces in Ghana. NRI Report, p. 2630.

Hodges, R., Farrell, G., 2004. Crop post-harvest: science and technology. In: Durables: Case Studies in the Handling and Storage of Durable Commodities, vol. 2. Blackwell Science, Oxford, UK; Ames, Ia.

Hodges, R.J., Buzby, J.C., Bennett, B., 2011. Post harvest losses and waste in developed and less developed countries: opportunities to improve resource use. J. Agric. Sci. 149, 37-45.

Holst, N., Meikle, W.G., Markham, R.H., 2000. Grain damage models for Prostephanus truncatus (Coleoptera: Bostrichidae) and Sitophilus zeamais (Coleoptera: Curculionidae) in rural maize stores in West Africa. J. Econ. Entomol. 93, 1338-1346.

Jankov, D., Inđić, D., Kljajić, P., Almaši, R., Andrić, G., Vuković, S., Grahovac, M., 2013. 
Initial and residual efficacy of insecticides on different surfaces against rice weevil Sitophilus oryzae (L.). J. Pest Sci. 86, 211-216.

Jayne, T.S., Argwings-Kodhek, Gem, 1997. Consumer response to maize market liberalization in urban Kenya. Food Policy 22, 447-457.

Kaaya, A.N., Kyamuhangi, W., 2010. Drying maize using biomass-heated natural convection dryer improves grain quality during storage. J. Appl. Sci. 10, 967-974.

Kaaya, A.N., Kyamuhangire, W., 2006. The effect of storage time and agroecological zone on mold incidence and aflatoxin contamination of maize from traders in Uganda. Int. J. Food Microbiol. 110, 217-223.

Kiobia, D., Tumbo, S., Cantillo, J., Rohde, B., Mallikarjunan, P., Mankin, R., 2015. Characterization of sounds in maize produced by internally feeding insects: investigations to develop inexpensive devices for detection of Prostephanus truncatus (Coleoptera: Bostrichidae) and Sitophilus zeamais (Coleoptera: Curculionidae) in small-scale storage facilities in sub-Saharan Africa. Fla. Entomol. 98, 405-409.

Lale, N.E.S., 1998. Preliminary studies on the effect of solar heat on oviposition, development and adult mortality of the cowpea bruchid Callosobruchus maculates (F.). Nigerian savanna. J. Arid Environ. 20, 157-162.

Lathiya, S.B., Ahmed, S.M., Pervez, A., Rizvi, S.W.A., 2007. Food habits of rodents in grain godowns of Karachi, Pakistan. J. Stored Prod. Res. 44, 41-46.

Lewis, L., Onsongo, M., Njapau, H., Schurz-Rogers, H., Luber, G., Kieszak, S., Nyamongo, J., Baker, L., Dahiye, A.M., Misore, A., DeCock, K., Rubin, C., the Kenya aflatoxicosis investigating group, 2005. Aflatoxin contamination of commercial maize products during an outbreak of acute aflatoxicosis in Eastern and Central Kenya. Environ. Health Perspect. 113, 1763-1767.

Maddala, G.S., 1991. A perspective on the use of limited-dependent and qualitative variables models in accounting research. Account. Rev. 66, 788-807.

Mankin, R.W., Hagstrum, D.W., Smith, M.T., Roda, A.L., Kairo, M.T., 2011. Perspective and promise: a century of insect acoustic detection and monitoring. Am. Entomol. 57, 30-44.

Mauyo, L.W., Okalebo, R., Kirkby, R.A., Buruchara, R., Ugen, M., Mengist, C.T., Anjichi, V.E., Musebe, R.O., 2007. Technical efficiency and regional market integration of cross-border bean marketing in Western Kenya and Eastern Uganda. Afr. J. Bus. Manag. 77-84.

Mutambuki, K., Ngatia, C.M., 2012. Assessment of grain damage and weight loss on farm stored maize in highlands areas of Bungoma district, Kenya. Journal of Agricultural Science and Technology B, 2, 349-361.

Mutungi, C.M., Affognon, H., Njoroge, A.W., Baributsa, D., Murdock, L.L., 2014. Storage of mung bean (Vigna radiata [L.] Wilczek) and pigeonpea grains (Cajanus cajan [L.] Millsp) in hermetic triple-layer bags stops losses caused by Callosobruchus maculatus (F.) (Coleoptera: bruchidae). J. Stored Prod. Res. 58,
39-47.

Nansen, C., Meikle, W.G., 2000. The biology of the larger grain borer, Prostephanus truncatus (Horn) (Coleoptera: Bostrichidae). Integr. Pest Manag. Rev. 7, 91-104.

Naziri, D., Quaye, W., Siwoku, B., Wanlapatit, S., Phu, T.V., Bennett, B., 2014. The diversity of postharvest losses in cassava value chains in selected developing countries. J. Agric. Rural Dev. Tropics Subtropics 115, 111-123.

Ng'ang'a, J., Mutungi, C., Imathiu, S., Affognon, H., 2016a. Effect of triple-layer hermetic bagging on mold infection and aflatoxin contamination of maize during multi-month on-farm storage in Kenya. J. Stored Prod. Res. 69, 119-128.

Ng'ang'a, J., Mutungi, C., Imathiu, S.M., Affognon, H., 2016b. Low permeability triplelayer plastic bags prevent losses of maize caused by insects in rural on-farm stores. Food Secur. 8.

Njoroge, A.W., Affognon, H.D., Mutungi, C.M., Manono, J., Lamuka, P.O. Murdock, L.L., 2014. Triple bag hermetic storage delivers a lethal punch to Prostephanus truncatus (Horn) (Coleoptera: Bostrichidae) in stored maize. J. Stored Prod. Res. 58, 12-19.

Njoroge, A.W., Affognon, H., Mutungi, C.M., Rohde, B., Richter, U., Hensel, O. Mankin, R.W., 2016. Frequency and time pattern differences in acoustic signals produced by Prostephanus truncatus (Horn) (Coleoptera: Bostrichidae) and Sitophilus zeamais (Motschulsky) (Coleoptera: Curculionidae) in stored maize. J. Stored Prod. Res. 69, 31-40.

Odeyemi, O.O., Ashamo, M.O., Akinkurolere, R.O., Olatunji, A.A., 2010. Resistance of strains of rice weevil, Sitophilus oryzae (Coleoptera: Curculionidae) to pirimiphos methyl. Julius-Kühn-Archiv (425), 167.

Panti-May, J.A., Betancourt, S.H., Pina, H.R., Peralta, S.M., 2012. Abundance and population parameters of commensal rodents in Yucatan, Mexico. Int. Biodeterior. Biodegrad. 66, 77-81.

Papke, L.E., Wooldridge, J.M., 1996. Econometric methods for fractional response variables with an application to $401(\mathrm{~K})$ plan participation rates. J. Appl. Econ. 11, 619-632.

Taylor, R.W.D., 1991. Resistance to grain fumigants and future prospects for their use. Pestic. Outlook 2, 22-24.

Wagacha, J.M., Muthomi, J.W., 2008. Mycotoxin problem in Africa: current status, implications to food safety and health and possible management strategies. Int. J. Food Microbiol. 124, 1-12.

Wilkin, D.R., Row lands, D.G., 1988. The bio-deterioration of stored cereals. HGCA Res. Rev. 3.

World Bank, 2010. Missing Food: the Case of Post-harvest Grain Loss in Sub-Saharan Africa, pp. 11-13. Report No. 60371-AFR. NW Washington, DC.

Yamane, T., 1967. Statistics: an Introductory Analysis, second ed. Harper and Row, New York. 